ANNA STAROSTA

\title{
Anti-crisis Management \\ Strategies. The case of companies in \\ the Greater Poland \\ Voivodeship.
}

\section{Introduction}

Businesses are increasingly faced with crises. A crisis may have a different course, derive from other reasons, or have a different impact scale. It is often associated with disruptions with the functioning of an organization and may result in adverse consequences (Barton 1993, p. 12, Oldcorn 1989, p. 237). It can also threaten the existence of the organization as well as prevent the attainment of its objectives (Herman 1963). In order to prevent, anticipate, and respond to crises quickly once they occur, anti-crisis management is necessary. However, if it is impossible to prevent a crisis, then it is necessary to apply appropriate measures in order to minimize its negative effects.

The purpose of this article is to present and systematize anti-crisis management strategies as well as results demonstrating the most frequently implemented anti-crisis measures in large companies in the Greater Poland Voivodeship)

\section{The Essence of Anti-crisis Management}

M. Sc. Anna Starosta Poznan University of Economics
Anti-crisis management focuses on the measures applied before, during and after 
a crisis. It is "a process, which anticipates the danger of crisis, carries out an analysis of its symptoms, measures limiting the negative consequences of the crisis and uses its factors to continue the development process" (Krzakiewicz 2008, p. 32). Anti-crisis management is a process consisting of four successive phases: crisis prevention, crisis preparation, crisis response from the business, and reconstruction (and evaluation of the applied anti-crisis measures).

Crisis prevention refers to measures applied to prevent a crisis. A manager must read the signals that warn against the possibility of an emerging crisis and take actions to mitigate its first symptoms. The next step in the process of anti-crisis management is preparation for the crisis. This activity is manifested in the preparation of anti-crisis plans, patterns of anti-crisis measures, and the diagnosis of anti-crisis measures. The next step in anti-crisis management is to implement anti-crisis actions. At this stage, it is important to coordinate and control the applied measures taken in preparation for the crisis. The last activity is to assess the organization's reaction to the crisis. At this stage, the organization assesses the applied measures, verifies them, draws conclusions, learns from its mistakes, and collects acquired knowledge.

The presented measures form a process that allows effective management in the event of the crisis and provides learning opportunities and preparation strategies to organizations for the next crisis (Krzakiewicz 2008, pp. 32-33).

\section{Types of Anti-crisis Strategies}

During preparation for crises businesses can develop crisis action plans and strategies that underpin the base of the ongoing measures implemented at the anti-crisis measurement stage.

The current literature proposes a number of types of the anti-crisis measures. The most typical anti-crisis solutions are (Wawrzyniak 1999, p. 67-70, Malewska 2003, p. 44-45):

- planning activities, including redefining the mission, vision, and goals of the company, adopting a new orientation about market opportunity, reorientating the product, introducing new management concepts, introducing formalized strategic planning,

- proposing activities related to the organization, including cost reduction, delaying repayment of liabilities, acquiring additional capital (e.g. securities, increasing initial capital, loans), renting assets, concluding amicable settlement proceedings with creditors, merging with a strategic partner, reducing the size of the business (e.g. liquidation or merger), diversifying activities,

Anti-crisis Management Strategies.

The case of companies

in the Greater Poland Voivodeship. 
changing managerial positions, changing product investments, purchasing new technologies, implementing quality management systems, implementing integrated information systems, changing price policy, changing organizational structure, outsourcing, changing organizational culture,

- changing motivational measures, including salary reduction, teamwork stimulation, creation of new motivational systems, change of work organization, employment reduction,

- controlling measures, including implementing additional financial control, and systematic controlling.

The proposed measures become the starting point for identifying the main types of anti-crisis strategy. To choose an appropriate strategy, one must properly determine the extent and causes of the crisis, time and intensity of its duration, methods of the organizational adaptation to the environment or employee involvement, and their commitment to overcoming the crisis.

Taking into account the duration and intensity of the crisis restructuring, one can distinguish between appropriate liquidation, growth, and bankruptcy strategies. The restructuring strategy focuses on crisis stabilization seeking to gain a competitive advantage. It is used to control crises. The liquidation strategy is a strategy that allows the bankruptcy of an enterprise by selling it or the implementation of the strategy maintaining solvency (the so-called voluntary liquidation). The growth strategy consists in taking aggressive measures to improve or strengthen the enterprise's competitive position, which is to be reflected in an increase in the market value of the organization. The last strategy is bankruptcy, which involves liquidating the enterprise without maintaining solvency (Zelek 2003, pp. 149-150).

Anti-crisis strategies are a response to the causes of the crisis and should be appropriate to its size. Moreover, anti-crisis measures depend on the causes and adaptions that can be distinguished between the company and business environment. Enterprises can respond to changes in the environment in either a proactive or reactive way. The causes of the crisis may, however, be related to the management or the scope and type of activity. Combining the causes and the reactions of organizations can create a matrix that shows four possible anti-crisis strategies: organizing, investment, withdrawal, and consolidation (Wawrzyniak 1999, pp. 68-69).

Investment strategy involves the development of the organization and search for opportunities in its environment. Next, the consolidation strategy focuses on the main activity of the enterprise and its strengths. Third, the reactive strategy focuses on reducing the costs and size of the business. The last strategy, the 
withdrawal strategy, concerns itself with the resignation of certain activities, leaving the markets and non-investment.

Another group of strategies shows various possible responses in view of the managerial approach to the crisis. The organization may not notice the danger and may not make the necessary changes; it can also minimize signs and treat them as a natural departure from the norm. Another reaction is solving problems immediately as they arise, which involves the identification of possible procedures and selection of the anti-crisis measures. The last possible strategy implemented by the enterprise is crisis prevention, where the emphasis is on detecting signals of the crisis, preparing appropriate anti-crisis measures, and preventing any negative consequences of the crisis (Wróblewski 2010).

The last group of strategies relates approaches to making anti-crisis changes in the organization. Here the prescriptive anti-crisis strategies are distinguished between those based on negotiations, analysis, and action-oriented strategies. The prescriptive strategies introduce changes in accordance with the plan, which should be carried out in the short term. This requires management authority, task orientation, and the ability and skills of overcoming resistance to changes. The strategy based on negotiations emphasizes the necessity for talks with members of the organization about the implementation of the anti-crisis plans. The normative strategies seek to build in the employees a sense of responsibility and commitment to make changes. Another strategy is the analytical strategy, which aims at making the optimal from the technical point of view of anticrisis decisions. To achieve this goal it is necessary to involve teams consisting of internal specialists as well as external consultants. In the action-oriented strategy the employees, who are to make the change, prepare the process of its inducing and use different approaches to solving problems (Krzakiewicz 2008, pp. 138-141).

Table 1 shows the detailed characteristics of the presented strategies.

Table 1. Types of Anti-crisis Strategies

\begin{tabular}{l|l|l}
\hline Classification & $\begin{array}{l}\text { Name of the } \\
\text { Strategy }\end{array}$ & \multicolumn{1}{c}{ Characteristics of the Strategy } \\
\hline $\begin{array}{l}\text { In view of the } \\
\text { approach and } \\
\begin{array}{l}\text { ways of making } \\
\text { changes, in view } \\
\text { of the participation } \\
\text { of employees in } \\
\text { the process of } \\
\text { introducing changes }\end{array}\end{array}$ & Prescriptive & $\begin{array}{l}\bullet \text { taking actions in accordance with a previously fixed plan } \\
\text { making changes in the short term } \\
\text { the necessity for the large management authority and } \\
\text { trust in the management } \\
\text { the necessity for the managers to have broad powers and } \\
\text { resources }\end{array}$ \\
\hline the strategy used in the case of acute crises
\end{tabular}

\section{$-\infty x$}

Anti-crisis Management Strategies.

The case of companies

in the Greater Poland Voivodeship. 


\begin{tabular}{|c|c|c|}
\hline & Negotiation & $\begin{array}{l}\text { - manager is the change initiator } \\
\text { - admitting the participation of the members of the } \\
\text { organization as to how the anti-crisis measures implement } \\
\text { - longer than in the prescriptive strategy time of this } \\
\text { strategy realization }\end{array}$ \\
\hline & Normative & $\begin{array}{l}\text { - a mental change of the members of the organization - } \\
\text { the members of the organization should have a sense of } \\
\text { responsibility for the company, the introducing changes } \\
\text { and for achieving the objectives } \\
\text { - use a professional help when modifying the behavior of } \\
\text { individuals and / or groups of the employees }\end{array}$ \\
\hline & Analytical & $\begin{array}{l}\text { - building management teams consisting of specialists and } \\
\text { consultants } \\
\text { - making decisions based on the knowledge and available } \\
\text { information } \\
\text { - focusing only on the technical aspects of the decision }\end{array}$ \\
\hline & $\begin{array}{l}\text { Action- } \\
\text { orientated }\end{array}$ & $\begin{array}{l}\text { - bigger than in other strategies the discretion of the } \\
\text { members of the organization } \\
\text { - lack of noticeable pressure from executives } \\
\text { - active employee participation in the implementation of } \\
\text { the strategy (for example, by delegating making changes } \\
\text { to selected employees) }\end{array}$ \\
\hline $\begin{array}{l}\text { In view of the } \\
\text { reasons and } \\
\text { adaptation to the } \\
\text { environment }\end{array}$ & Organizing & $\begin{array}{l}\text { - reactive adaptation to the environment } \\
\text { - involves the reaction to the crisis causes related to the } \\
\text { management } \\
\text { - expresses itself through cost and employment reductions, } \\
\text { sale of assets, finance restructuring, changing the } \\
\text { organizational structure }\end{array}$ \\
\hline & Investment & $\begin{array}{l}\text { - proactive adaptation to the environment } \\
\text { - involves the reaction to the crisis causes related to the } \\
\text { management } \\
\text { - activities related to the investment in new products or } \\
\text { market segments, in human resources, } \\
\text { - the introduction of new management concepts } \\
\text { - activities related to other market actors: a fusion with } \\
\text { another company, strategic alliances, takeovers, mergers, }\end{array}$ \\
\hline & Withdrawal & $\begin{array}{l}\text { - reactive adaptation to the environment } \\
\text { - reaction of the company as a response to the causes of the } \\
\text { crisis related to the scope and type of activity } \\
\text { - limiting the scale of the business, employment reduction } \\
\text { the abandonment of certain departments, leaving specific } \\
\text { markets, limiting the range of products }\end{array}$ \\
\hline
\end{tabular}




\begin{tabular}{|c|c|c|}
\hline & Consolidation & $\begin{array}{l}\text { - proactive adaptation to the environment } \\
\text { - the enterprise's activities directed at reducing the causes } \\
\text { of the crisis associated with the scope and type of activity } \\
\text { - redefining business activity } \\
\text { - concentration only on selected markets } \\
\text { - the introduction of the cost strategy } \\
\text { - disclosing quality problems }\end{array}$ \\
\hline \multirow[t]{4}{*}{$\begin{array}{l}\text { In view of the } \\
\text { duration and } \\
\text { intensity of the crisis }\end{array}$} & $\begin{array}{l}\text { Restructuring } \\
\text { option }\end{array}$ & $\begin{array}{l}\text { - stabilization of the crisis and in the long term achieving } \\
\text { lasting improvement of the situation in the enterprise } \\
\text { - enterprise activities are directed mainly at restructuring } \\
\text { aimed at removing the causes of the crisis }\end{array}$ \\
\hline & $\begin{array}{l}\text { Liquidation } \\
\text { option }\end{array}$ & $\begin{array}{l}\text { - the main objective is to generate maximum liquidation } \\
\text { capital } \\
\text { - he enterprise sale and liquidation strategies }\end{array}$ \\
\hline & $\begin{array}{l}\text { Growth } \\
\text { option }\end{array}$ & $\begin{array}{l}\text { - proactive measures designed to strengthen the enterprise } \\
\text { through investments or integration } \\
\text { - a prerequisite for the implementation of this type of the } \\
\text { strategy is to have by the enterprise capital } \\
\text { - examples of measures are strategic alliances, mergers and } \\
\text { takeovers }\end{array}$ \\
\hline & $\begin{array}{l}\text { Bankruptcy } \\
\text { option }\end{array}$ & $\begin{array}{l}\text { - liquidation of the enterprise without maintaining solvency } \\
\text { - this strategy is the result of poor economic condition }\end{array}$ \\
\hline \multirow{4}{*}{$\begin{array}{l}\text { In view of the } \\
\text { managerial approach } \\
\text { to crisis }\end{array}$} & Unnoticing & - receiving signals as non-essential, not requiring action \\
\hline & $\begin{array}{l}\text { Underestima- } \\
\text { tion }\end{array}$ & $\begin{array}{l}\text { - perception of signals as a natural departure from the } \\
\text { norm, in which the current modifications of the activities } \\
\text { are introduced }\end{array}$ \\
\hline & $\begin{array}{l}\text { Solving prob- } \\
\text { lems in a cri- } \\
\text { sis situation }\end{array}$ & $\begin{array}{l}\text { - in a crisis situation the necessary amendments are made } \\
\text { to identify weakness, identify possible ways of action and } \\
\text { their assessment }\end{array}$ \\
\hline & $\begin{array}{l}\text { Constant } \\
\text { prevention of } \\
\text { crisis situa- } \\
\text { tions }\end{array}$ & $\begin{array}{l}\text { - crisis seen as a stage of development of the organization } \\
\text { - enterprises must take action within the framework of } \\
\text { the preparation, prevention, response to the crisis and } \\
\text { evaluation of measures }\end{array}$ \\
\hline
\end{tabular}

Source: own study based on: Krzakiewicz 2008, pp. 138-141; Wawrzyniak 1999, pp. 68-69;

Wieczerzyńska 2009, p. 85; Zelek 2003, pp. 149-150; Wróblewski 2010 
A very large role in the creation and implementation of the specific anti-crisis strategy managers play (their skills, attitudes, behaviour), who provides a point of reference for both the members of the organization, its shareholders and the public opinion. The responsibility of dealing with crisis rests on him (King 2007, p. 187). As a result of the complexity of the measures taken at this stage of the anti-crisis management, managers should (Krzakiewicz 2003, p. 38):

- explain the anti-crisis strategy, objectives and overlapping dependencies in a clear and well-defined way,

- spread the ideas of the new anti-crisis strategy among employees,

- obtain adequate resources for its implementation,

- take decisions aimed at matching the organizational structure to the new strategy.

\section{The Most Common Anti-crisis Measures Taken in Wielkopolska's (Greater Poland) Businesses}

In 2013 the author conducted research on a sample of 331 large companies (those operating with more than 249 employees) in Wielkopolska, 60 of which gave the answer, which represents $18.13 \%$ of the studied population. The research was based on random sampling. The applied research instrument was a questionnaire (consisting entirely of closed - ended questions) addressed to executives, which dealt with the symptoms and causes of crisis as well as the most frequently implemented anti-crisis measures. Among the surveyed companies 59 indicated the occurrence of the symptoms of crisis, and 53 adopted anti-crisis measures, which are presented on figure 1.

An analysis of the results of the research allows us to conclude that cost reduction was the most frequently performed operation (88\%). In more than every other company, financial controls were implemented. Over $51 \%$ of indications concerned employment reduction. Also, an important group of actions were those concerning changes in the organizational structure. More than $41 \%$ of surveyed enterprises applied activities in this field. At a similar level of indications there is also a change in the organization of work, which is directly linked with the structural changes. Every third company redefined its mission and vision. Less than $30 \%$ of the surveyed enterprises took measures associated with changes in quality and informatics. $28 \%$ of the all surveyed enterprises modified the personnel policy on both wage reduction and necessary changes in the executive positions. At a similar level of indications there are activities related to the product, namely product investment or product reorientation. 


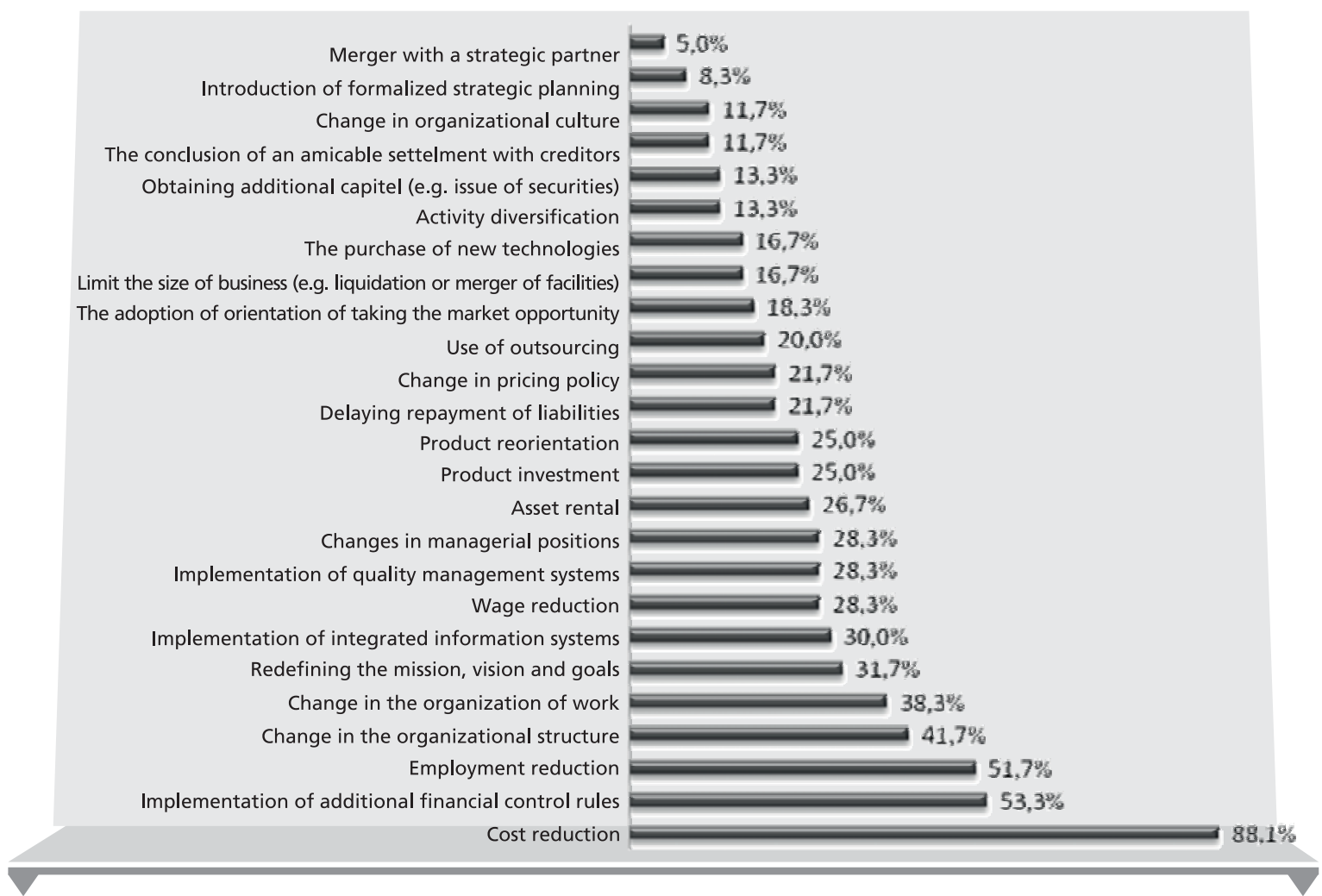

Figure 1. Analysis of Taken Anti-crisis Measures

Source: a study based on my own research

In the majority of the enterprises the taken anti-crisis measures were not applied individually. Six anti-crisis measures were most often implemented simultaneously (over 15\% of indications). The largest frequency of indications concerning the amount of anti-crisis measures taken at the same time was in the range between four and seven. Such an amount of measures was chosen in over $50 \%$ of cases. Both larger and smaller number of taken initiatives fluctuated in the range between $1.9 \%$ - 5.7\%. Please see figure 2 .

Taking into account that only a few enterprises implement single anti-crisis measures, therefore attention should be paid to the cross relationship between the undertaken projects. The presented relations apply only to those actions that were mostly performed together. In the case of the enterprises that applied cost reduction over $60 \%$, also the implementation of financial control and employment reduction principles were also chosen. The enterprises that implemented the principles of financial control in $56.3 \%$ also chose structural solutions, namely 


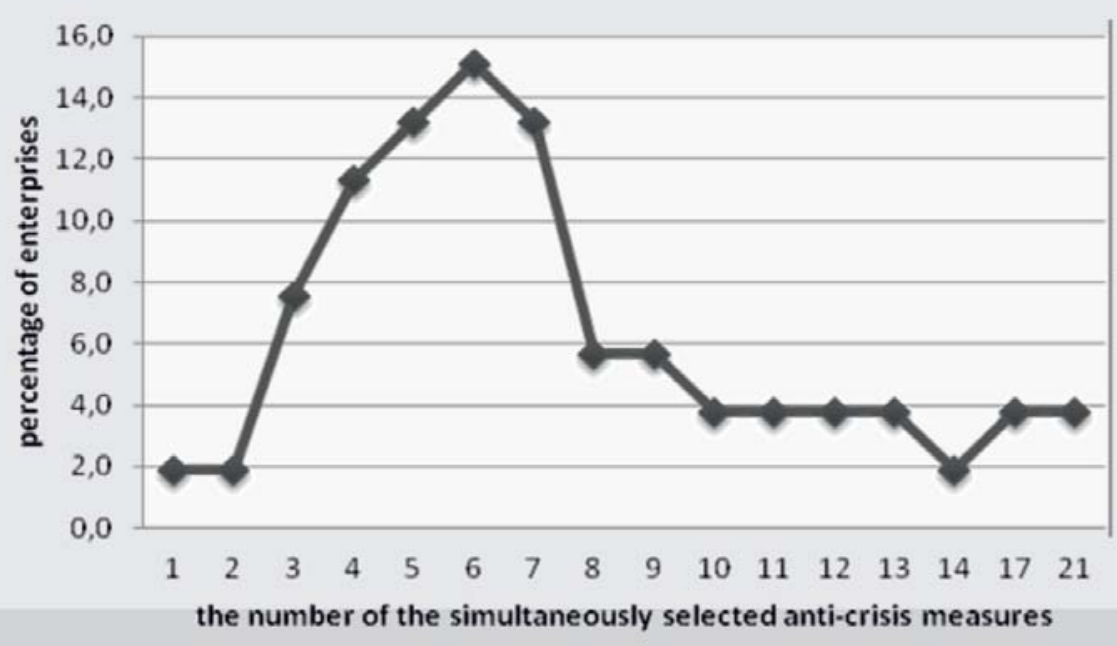

Figure 2. Frequency Distribution in Chosen Anti-crisis Measures

Source: a Study Based on My own Research

changes in the structure, in the organization of work and as a result of these transformations employment reduction. In the case of the enterprises that decided to rent assets, the most commonly taken activity (besides cost reduction) was employment reduction.

In addition, more than half of the enterprises paid attention to the necessary changes in the IT infrastructure and quality management systems. Employment reduction, changes in executive positions, and a change in the organization of work had also a high number of indications. Enterprises that entered into settlement proceedings with creditors, in over $70 \%$ of cases, were slow to pay their obligations and rented their assets. In over $80 \%$ of cases, organizations implemented additional financial rules. In addition to the most common introduced measures such as employment reduction and structural changes (85.7\%), the surveyed enterprises in more than $50 \%$ of the cases sought to change the profile of business by redefining the mission and vision or the adoption of the orientation of taking the market opportunity and to focus on their core business by outsourcing (simultaneous $57 \%$ of indications). Although employment reduction was often pointed out, enterprises that chose this action also chose three other initiatives.

Cost reduction, change in organizational structure (nearly 65\%), and the implementation of additional rules for financial control were dominating. In 
the case of a comprehensive interpretation of the research results concerning the taken anti-crisis measures, a high number of indications have also shown a change in managerial positions and changes in organizational structure.

The distribution of these indications shaped in a similar way, although it may be noted that in the case of changes in personnel more enterprises also undertook other activities. In both cases more than $65 \%$ of enterprises pointed to the concomitant use of additional financial controls; and in the case of $80 \%$ to employment reduction. A larger number of indications in the case of personnel changes have also product investments and implementation of integrated information systems (respectively $58.8 \%$ and $52.9 \%$ ).

\section{Summary}

The results of the research regarding the taken anti-crisis measures show two dominant types of strategies. In most enterprises one of the forms of reactive activities was focused on. This resulted in the creation of more transparent procedures and the reduction of broadly understood costs. It can also be said that companies applied the strategy of organizing activities. Taking into account the divisions of the various anti-crisis strategies regarding causes and adaptations, a company takes actions that emerge based primarily on one factor: consolidation.

Essentially, businesses focus on: the product, its redefinition, improving quality management, information systems, and efforts focusing on the core business. The taken measures relate not only to coping with the crisis, but also development. Taking into account the different typologies of anti-crisis measures, the implemented solutions comprised both restructuring as well as growth.

\section{Summary}

Anti-crisis Management Strategies: an Empirical Approach

A growing need to function in a crisis makes enterprises take measures related to the prevention and prediction of crises and when they occur to react quickly. Effective crisis coping requires anti-crisis management. However, it is not always possible to prevent crises; moreover, enterprises are forced to make a number of anti-crisis measures. In general, people took two measures. The first concerns the creation of more transparent procedures and reduction of broadly understood costs. The second one involves 
concentration on the main activities of the enterprise and the product, its redefining, and improving quality management. This solution points to the implementation of two types of key anticrisis strategies: organizing activities and consolidation.

Keywords: Anti-crisis Management, Anti-crisis Measures, Anti-crisis Strategies.

\section{Streszczenie}

\section{Strategie zarządzania antykryzysowego - ujęcie empiryczne}

Coraz częstsza konieczność funkcjonowania w sytuacji kryzysowej wymusza na przedsiębiorstwach podejmowania działań związanych z zapobieganiem i przewidywaniem kryzysów, a w momencie ich wystąpienia na szybkie reagowanie. Skuteczne zmaganie się z kryzysem wymaga zarządzania antykryzysowego. Nie zawsze jednak udaje się zapobiec kryzysom i przedsiębiorstwa zmuszone są podejmować szereg działań antykryzysowych. Najczęściej podejmują one działania w dwóch obszarach. Pierwszy dotyczy stworzenia bardziej przejrzystych procedur postępowania oraz ograniczenia szeroko pojmowanych kosztów. Drugi natomiast obejmuje koncentrację na głównej działalności przedsiębiorstwa oraz na produkcie, jego redefiniowaniu oraz usprawnieniu zarządzania jakością. Wskazuje to na realizowanie dwóch rodzajów strategii antykryzysowej - porządkowania działalności oraz konsolidacji.

Stowa

kluczowe: zarzadzanie antykryzysowe, dziatania antykryzysowe, strategie antykryzysowe

\section{References}

1. Barton R.M. (1993), The Crisis Management, Oxford Press Publishers, Oxford.

2. Herman Ch.F. (1963), Some Consequences of Crisis Which Limit the Viability of Organizations, "Administrative Science Quartely", No 8.

3. King G. (2007), Narcissism and Effective Crisis Management: A review of Potencial Problems and Pitfalls, "Journal of Contingencies and Crisis Management", Vol. 15 No. 4.

4. Krzakiewicz K. (2003), Strategia i taktyka w zarzadzaniu antykryzysowym, in: J. Skalik (red.), Zachowania organizacji wobec zjawisk kryzysowych, Cornetis, Wrocław. 
5. Krzakiewicz K. (2008), Zarzadzanie antykryzysowe w organizacji, Wyd. Akademii Ekonomicznej w Poznaniu, Poznań.

6. Malewska K. (2003), Strategie zarządzania kryzysem w przedsiębiorstwie, in: J. Skalik (red.), Zachowania organizacji wobec zjawisk kryzysowych, Cornetis, Wrocław.

7. Oldcorn R. (1989), Management, MacMillan, London.

8. Wawrzyniak B. (1999), Odnawianie przedsiębiorstwa. Na spotkanie XXI wieku, Poltext, Warszawa.

9. Wieczerzyńska B. (2009), Kryzys w przedsiębiorstwie, CeDeWu Wydawnictwo Fachowe, Warszawa.

10. Wróblewski R. (2010), Wybrane problemy zarządzania przedsiębiorstwem w sytuacjach kryzysowych, Zeszyty Naukowe Uniwersytetu PrzyrodniczoHumanistycznego w Siedlcach, Nr 87, Seria: Administracja i Zarządzanie, Siedlce.

11. Zelek A. (2003), Zarzadzanie kryzysem w przedsiębiorstwie. Perspektywa strategiczna, Orgmasz, Warszawa. 